\title{
PReS13-SPK-1472: Science of muscle training in inflammatory disease
}

\author{
M Van Brussel \\ From 20th Pediatric Rheumatology European Society (PReS) Congress \\ Ljubljana, Slovenia. 25-29 September 2013
}

Idiopathic inflammatory myopathies (IIMs) embody a heterogeneous group of conditions with a chronic autoimmune inflammatory process affecting a variety of muscle, skin and internal organs. IIMs are clinically characterized by (proximal) muscle weakness and decreased muscle endurance. Exercise training is increasingly utilized as a non-pharmacological intervention in the clinical management of pediatric patients with chronic inflammatory conditions; however, the efficacy, safety and effects on the course of the conditions should be topic of investigation. Clinicians attempting to prescribe exercise training in children with chronic inflammatory conditions face a dilemma. Exercise and physical training may encourage health e.g. by stimulating growth factors and tissue anabolism. In contrast, if sufficiently intense, exercise might stimulate inflammatory cytokines and lead to a catabolic state. Finding the optimal level of exercise in children and adolescents with an inflammatory condition can be difficult because the underlying disease can be associated with increased basal energy, malnutrition and inflammation, all of which promote tissue catabolism even at rest. Therefore, not only the efficacy and safety of training but also effects on the course of the conditions should be topic of investigation. The field of exercise physiology provides knowledge that might be of clinical importance when examining, testing and training muscle performance in children and adolescents with chronic inflammatory conditions.

\section{Disclosure of interest}

None declared.

Wilhelmina Children's Hospital, University Medical Center Utrecht, The Netherlands, Utrecht, The Netherlands

(c) 2013 Van Brussel; licensee BioMed Central Ltd. This is an Open Access article distributed under the terms of the Creative Commons Attribution License (http://creativecommons.org/licenses/by/2.0), which permits unrestricted use, distribution, and reproduction in any medium, provided the original work is properly cited. The Creative Commons Public Domain Dedication waiver (http://creativecommons.org/publicdomain/zero/1.0/) applies to the data made available in this article, unless otherwise stated.
Cite this article as: Van Brussel: PReS13-SPK-1472: Science of muscle training in inflammatory disease. Pediatric Rheumatology 2013

Submit your next manuscript to BioMed Central and take full advantage of:

- Convenient online submission

- No space constraints or color figure charges

- Immediate publication on acceptance

- Inclusion in PubMed, CAS, Scopus and Google Scholar

- Research which is freely available for redistribution \\ C Biomed Central}

doi:10.1186/1546-0096-11-S2-I9 11(Suppl 2):19.

- Thorough peer review

Published: 5 December 2013 www.biomedcentral.com/submit 